\title{
Resection rates and postoperative mortality in 7,899 patients with lung cancer
}

\author{
R.A.M Damhuis*, P.R. Schütte ${ }^{* *}$
}

Resection rates and postoperative mortality in 7,899 patients with lung cancer. R.A.M. Damhuis, P.R. Schütte. (CERS Journals Ltd 1996.

ABSTRACT: Postoperative death used to be an important complication of resections for lung cancer, especially in elderly patients. To support decision making in a general situation, contemporary results and prognostic factors were evaluated.

The computer records of 7899 lung cancer patients, diagnosed from 1984 until 1992 in hospitals connected to the Rotterdam Cancer Registry, were analysed to evaluate resection rates and 30 day postoperative mortality.

Resections were carried out in $20 \%$ of all patients. In patients $70 \mathrm{yrs}$ of age and older, the resection rate was $14 \%$, and in younger patients $26 \%$. The postoperative mortality was $3.1 \%$; $3.6 \%$ for males and $0.4 \%$ for females. According to multivariate analysis, age and extent of surgery were the major determinants of operative risk. For patients aged 0-59, 60-69 and $\geq 70$, postoperative mortality rates were $1.4,3.5$ and $4.0 \%$, respectively. The operative risk was $5.7 \%$ after pneumonectomy, $4.4 \%$ after bilobectomy, and $1.4 \%$ after lesser resections. Pneumonectomies were performed less often in elderly patients: $27 \%$ of operations in patients $\geq 70$ yrs versus $37 \%$ of operations in younger patients.

Age appears to be related to treatment choice and postoperative mortality in patients with lung cancer. However, even in patients over 70 yrs of age, resections can be performed at acceptable risk, implying that chronological age should not automatically determine treatment decisions.

Eur Respir J., 1996, 9, 7-10.
*Comprehensive Cancer Center Rotterdam, Rotterdam, The Netherlands **Dept of Surgery, Merwede Hospital, Dordrecht, The Netherlands.

Correspondence: R.A.M. Damhuis Comprehensive Cancer Center Rotterdam P.O. Box 289 3000 AG Rotterdam

The Netherlands

\section{Keywords: Age} lung neoplasms postoperative mortality

Received: February 211995

Accepted after revision June 161995
Surgical resection is at present the only treatment that may offer cure for patients with lung cancer. In many cases, however, surgery is withheld because of the extent of disease or the physical condition of the patient. In patients with operable tumours, the potential benefit of surgery has to be balanced against postoperative morbidity and mortality, particularly in the elderly. The actual treatment decisions will be dependent on the appraisal of results from the literature, which are derived mainly from specialized centres. Several institutes have shown that, with judicious selection of patients, resections can carry an operative risk of less than 5\% [1-3]. These results, however, may not be representative for the general situation due to variation between hospitals and differences with respect to the selection of cases. This was illustrated by a large population-based study from California [4], which reported mortality rates that far exceeded those of the major cancer centres. Another study by WhitTLE et al. [5] demonstrated that this was particularly true for elderly patients undergoing pneumonectomy.

In order to assess the operative risk in a general situation, we studied resection rates and postoperative mortality in the southwestern part of The Netherlands, an area with 2.2 million inhabitants and 22 hospitals.

\section{Patients and methods}

The Rotterdam Cancer Registry started in 1982 in three hospitals and the number of participating hospitals expanded gradually thereafter. In 1989, full coverage was achieved of the southwestern part of The Netherlands, an area with 22 hospitals and 2.2 million inhabitants. This area comprises one department of Thoracic Surgery, which is part of the academic hospital. Most patients with lung cancer are, however, operated on by general surgeons with special training in lung surgery.

Newly diagnosed cancer patients are notified to the registry by means of notes from pathology departments and hospital discharge diagnoses. After notification, trained registrars collect data from the clinical records. These records are examined at least 3 months after diagnosis, thus enabling a limited follow-up. Death certificates are not available due to privacy regulations. Tumour site and morphology are classified according to the rules of the International Classification of Diseases for Oncology (ICD-O) Tumour stage was registered according to the tumour/node/metastasis (TNM) regulations [6, 7]. Co-existing medical disorders and other clinical parameters were not recorded.

Information on all registered patients diagnosed with 
Table 1. - Resection rates in 6,724 men and 1,175 women with lung cancer

\begin{tabular}{|c|c|c|c|c|c|c|}
\hline & & Males & & & Females & \\
\hline & $\mathrm{n}$ & $\begin{array}{c}\text { Resection } \\
\text { rate } \%\end{array}$ & p-value & $\mathrm{n}$ & $\begin{array}{l}\text { Resection } \\
\text { rate \% }\end{array}$ & p-value \\
\hline Age & & & & & & \\
\hline $0-59$ yrs & 1179 & 27 & $<0.001$ & 418 & 27 & $<0.001$ \\
\hline $60-69$ yrs & 2150 & 27 & & 365 & 21 & \\
\hline$\geq 70$ yrs & 3395 & 14 & & 392 & 14 & \\
\hline Morphology & & & & & & \\
\hline Squamous cell & 2672 & 31 & $<0.001$ & 265 & 29 & $<0.001$ \\
\hline Adenocarcinoma & 1040 & 35 & & 326 & 40 & \\
\hline Small cell & 1106 & 2 & & 252 & 3 & \\
\hline Other/not specified & 1906 & 9 & & 332 & 9 & \\
\hline Year of diagnosis & & & & & & \\
\hline 1984-1989 & 3540 & 21 & 0.07 & 606 & 20 & 0.63 \\
\hline 1990-1992 & 3184 & 19 & & 569 & 21 & \\
\hline
\end{tabular}

lung cancer between January 1984 and December 1992 was evaluated. Twenty eight patients with carcinoma in situ, 16 with sarcomas and 47 with carcinoid tumours were excluded, as were metachronous tumours. For purposes of tabulation and analysis, postsurgical TNM categories were combined, as were ICD-O codes. For synchronous tumours, only the most advanced lesion was used in the analyses. With respect to type of treatment, only resectional operations were evaluated. Operative mortality was defined as death within 30 days of operation. Thirty two patients who received preoperative radiotherapy or chemotherapy were included for the analysis of resection rates but excluded from the analysis of postoperative mortality, to enable a valid evaluation of the stage parameter. One of these patients died postoperatively. For the evaluation of trends, two periods were defined (1984-1989 and 1990-1992) with approximately equal numbers of patients.

Resection rates and operative mortality rates were tabulated and evaluated with chi-square statistics. Operative mortality was then analysed using multivariate logistic regression. The categories of the variables were represented by indicator variables and their predictive value was assessed with the p-value of the log likelihood. Only variables significantly improving the fit of the model $(p<0.05)$, were included in the final model. Odds ratios were calculated together with $95 \%$ confidence intervals, and represent the relative risk as compared to the reference category.

\section{Results}

In the period 1984-1992, 7,899 patients had been diagnosed with lung cancer, $9 \%$ on clinical grounds, $14 \%$ by cytology, and the remainder by histological examination. Of these patients, $20 \%$ underwent resection (table 1). For patients 70 years of age and older, the resection rate was half that for younger patients. Patients with adenocarcinoma were more frequently treated by surgery than those with squamous cell carcinoma; resections were rare in patients with small cell carcinoma. Gender and year of diagnosis were not significantly related to treatment choice. Female patients were generally younger than males and were more often diagnosed with adenocarcinoma.

Table 2. - Postoperative mortality in 1,577 patients with lung cancer

\begin{tabular}{|c|c|c|c|c|}
\hline & $\mathrm{n}$ & $\begin{array}{c}\text { Postop } \\
\text { mortality } \\
\%\end{array}$ & p-value* & $\begin{array}{c}\text { OR** } \\
(95 \% \mathrm{CI})\end{array}$ \\
\hline $\begin{array}{l}\text { Gender } \\
\text { Male } \\
\text { Female }\end{array}$ & $\begin{array}{r}1338 \\
239\end{array}$ & $\begin{array}{l}3.6 \\
0.4\end{array}$ & 0.01 & NS \\
\hline $\begin{array}{l}\text { Age } \\
0-59 \text { yrs } \\
60-69 \text { yrs } \\
\geq 70 \text { yrs }\end{array}$ & $\begin{array}{l}418 \\
638 \\
521\end{array}$ & $\begin{array}{l}1.4 \\
3.5 \\
4.0\end{array}$ & 0.06 & $\begin{array}{c}1 \\
2.6(1.0-6.4) \\
3.6(1.4-8.9)\end{array}$ \\
\hline $\begin{array}{l}\text { Morphology } \\
\text { Squamous cell } \\
\text { Adenocarcinoma } \\
\text { Small cell } \\
\text { Other }\end{array}$ & $\begin{array}{r}881 \\
485 \\
26 \\
185\end{array}$ & $\begin{array}{l}3.4 \\
2.7 \\
3.9 \\
2.7\end{array}$ & 0.87 & NS \\
\hline $\begin{array}{l}\text { Type of surgery } \\
\text { Pneumonectomy } \\
\text { Bilobectomy } \\
\text { Lobectomy/other }\end{array}$ & $\begin{array}{l}530 \\
135 \\
912\end{array}$ & $\begin{array}{l}5.7 \\
4.4 \\
1.4\end{array}$ & $<0.001$ & $\begin{array}{c}4.5(2.3-8.8) \\
3.5(1.3-9.4) \\
1\end{array}$ \\
\hline $\begin{array}{l}\text { Stage } \\
1 \\
\text { II } \\
\text { III/IV/X }\end{array}$ & $\begin{array}{r}1022 \\
272 \\
283\end{array}$ & $\begin{array}{l}2.9 \\
3.7 \\
3.2\end{array}$ & 0.82 & NS \\
\hline $\begin{array}{l}\text { Year of diagnos } \\
1984-1989 \\
1990-1992\end{array}$ & $\begin{array}{l}852 \\
725\end{array}$ & $\begin{array}{l}2.8 \\
3.5\end{array}$ & 0.47 & NS \\
\hline
\end{tabular}

*: univariate analysis: $* *$ : multivariate analysis. OR: odds ratio; 95\% CI: 95\% confidence interval; ns: nonsignificant.

Table 3. - Association between age and type of surgery

\begin{tabular}{lccc}
\hline $\begin{array}{l}\text { Age } \\
\text { yrs }\end{array}$ & $\begin{array}{c}\text { Pneumonectomy } \\
\%\end{array}$ & $\begin{array}{c}\text { Bilobectomy } \\
\%\end{array}$ & $\begin{array}{c}\text { Lesser } \\
\%\end{array}$ \\
\hline $0-59$ & 38 & 10 & 52 \\
$60-69$ & 36 & 9 & 55 \\
$\geq 70$ & 27 & 8 & 65 \\
\hline
\end{tabular}


Table 4. - Review of selected recent studies reporting surgical mortality in patients aged 70 yrs and older

\begin{tabular}{|c|c|c|c|c|c|c|c|c|c|c|}
\hline \multirow{3}{*}{$\begin{array}{l}\text { First } \\
\text { author }\end{array}$} & \multirow{3}{*}{ [Ref.] } & \multirow{3}{*}{$\begin{array}{c}\geq 70 \text { yrs } \\
\%^{*}\end{array}$} & \multirow{3}{*}{ Period } & \multicolumn{7}{|c|}{ Operative mortality at $\geq 70$ yrs } \\
\hline & & & & \multicolumn{2}{|c|}{ Overall } & \multicolumn{2}{|c|}{ Pneumonectomy } & \multicolumn{2}{|c|}{$\begin{array}{l}\text { Lesser } \\
\text { resections }\end{array}$} & \multirow[t]{2}{*}{ Definition } \\
\hline & & & & $\mathrm{n}$ & $\%$ & $\mathrm{n}$ & $\%$ & $\mathrm{n}$ & $\%$ & \\
\hline GINSBERG & [2] & 20 & 1979-1981 & $32 / 453$ & 7 & $5 / 85$ & 6 & $27 / 368$ & 7 & 30 day \\
\hline KOHMAN & [11] & 20 & 1972-1984 & 7/97 & 7 & - & - & - & - & Hospital \\
\hline DenefFe & [12] & 10 & 1970-1984 & $8 / 71$ & 11 & - & - & - & - & 30 day \\
\hline ROXBURGH & [13] & 24 & 1983-1986 & $3 / 43$ & 7 & $2 / 22$ & 9 & $1 / 21$ & 5 & Hospital \\
\hline IsHIDA & [3] & 25 & 1974-1989 & $6 / 167$ & 4 & $0 / 11$ & 0 & $6 / 156$ & 4 & Hospital \\
\hline WhitTLE & [5] & - & 1983-1985 & $75 / 903$ & 8 & $16 / 94$ & 17 & $59 / 809$ & 7 & 30 day \\
\hline Patel & [14] & - & 1985-1990 & & - & $17 / 197$ & 9 & - & - & Hospital \\
\hline ROMANO** & [4] & 30 & 1983-1986 & $295 / 3831$ & 8 & $65 / 332$ & 20 & $230 / 3499$ & 7 & Hospital \\
\hline GEBITEKIN & [15] & 22 & 1980-1988 & 13/145 & 9 & $5 / 47$ & 11 & 8/98 & 8 & Hospital \\
\hline $\mathrm{Au}$ & [16] & - & 1980-1987 & $23 / 212$ & 11 & $15 / 70$ & 21 & $8 / 142$ & 6 & 30 day \\
\hline This study & - & 33 & 1984-1992 & $21 / 521$ & 4 & $11 / 140$ & 8 & 10/381 & 3 & 30 day \\
\hline
\end{tabular}

*: proportion of operated patients in the study, being 70 years or older; $* *$ : denominators were estimated using the reported tables.

According to univariate analysis, mortality rates were dependent on gender and type of resection (table 2). The operative risk was $3.6 \%$ in males and $0.4 \%$ in females. For pneumonectomy, bilobectomy and smaller operations, the rates were 5.7, 4.4 and $1.4 \%$, respectively. Multivariate analysis revealed that the relative risk increased with age and extent of operation. For patients aged $60 \mathrm{yrs}$ and over, the operative risk was $3.7 \%$ in comparison to $1.4 \%$ for younger patients. The proportion of pneumonectomies decreased with age from $38 \%$ for patients below $60 \mathrm{yrs}$ of age to $36 \%$ for those aged 60-69 yrs, and to $27 \%$ for patients 70 yrs and older $(\mathrm{p}<0.001)$ (table 3).

\section{Discussion}

Postoperative death used to be an important complication of surgical resections for lung cancer [8-10]. In recent decades, however, mortality rates declined due to careful selection of patients and advances in preoperative, anaesthetic and postoperative management. The $3.1 \%$ mortality that we encountered is comparable with results reported by specialized centres [1-3] and contradicts reports from the USA that mortality rates would be higher for population-based series [4, 5]. Direct comparison between studies are, however, hampered by differences in definitions and selection criteria. For example, the in-hospital definition may yield a $31 \%$ higher rate than the 30 days definition [11]. Other important confounders are the age distribution and the extent of surgery. Table 4 demonstrates that the proportion of patients aged 70 yrs and over may range 10-33\%, and that, within that age group, the proportion of pneumonectomies may range $7-51 \%$.

The operative risk in patients aged $70 \mathrm{yrs}$ and older (8\% after pneumonectomy and 3\% after lesser resections), appears acceptable given the fair life expectancy at 70 yrs of age, 11.4 yrs for men and 15.3 yrs for women [17]. Other studies, however, reported mortality rates ranging $0-21 \%$ following pneumonectomy and $4-8 \%$ after lesser resections (table 4). Since treatment decisions may depend on estimates of operative mortality, local results should be available to support decision making by physician and patient. Mortality rates derived from the literature may not be representative because of publication bias and different selection criteria.

Apart from age and extent of surgery, no additional prediction variables were identified in multivariate analysis. The operative risk in women was low but it was based only on one event, and female patients were on average younger than men. Our analyses were restricted to the items collected by the cancer registry. Several other studies have collected more detailed information and reported that prediction could be improved by parameters of the cardiovascular and pulmonary function $[1,10$, 11, 18]. Absolute contraindications are hard to define, since additional testing of high risk patients may select a subgroup in which surgery is justified $[19,20]$. Given the small absolute risks encountered in contemporary series, future studies looking for medical criteria for inoperability will require an extensive sample size.

In the Rotterdam region, $24 \%$ of patients with nonsmall cell lung cancer underwent resection. For patients aged $70 \mathrm{yrs}$ or older, the resection rate is significantly lower, probably reflecting coexisting cardiovascular disease or respiratory problems. Selection criteria for elderly patients may have been too strict, although one third of operated patients were 70 years or older, which is higher than the proportions in other recent series (table 4). Our results demonstrate that patients with lung cancer should not be excluded from surgery on the basis of chronological age.

\section{References}

1. Nagasaki F, Flehinger BJ, Martini N. Complications of surgery in the treatment of carcinoma of the lung. Chest 1982; 82: 25-29.

2. Ginsberg RJ, Hill LD, Eagan RT, et al. Modern thirty day operative mortality for surgical resections in lung cancer. J Thorac Cardiovasc Surg 1983; 86: 654-658. 
3. Ishida T, Yokoyama H, Kaneko S, Sugio K, Sugimachi K. Long-term results of operation for non-small cell lung cancer in the elderly. Ann Thorac Surg 1990; 50: 919-922.

4. Romano PS, Mark DH. Patient and hospital characteristics related to in-hospital mortality after lung cancer resection. Chest 1992; 101: 1332-1337.

5. Whittle J, Steinberg EP, Anderson GF, Herbert R. Use of Medicare claims data to evaluate outcomes in elderly patients undergoing lung resections for lung cancer. Chest 1991; 100: 729-734.

6. Harmer M. TNM Classification of Malignant Tumours. 3rd edn. Geneva; International Union Against Cancer 1978.

7. Hermanek P, Sobin LH. TNM Classification of Malignant Tumours, 4th edn. Berlin; Springer-Verlag, 1987.

8. Weiss W. Operative mortality and five year survival rates in patients with bronchogenic carcinoma. Am J Surg 1974; 128: 799-804.

9. McNeil BJ, Weichselbaum R, Pauker SG. Fallacy of the five year survival in lung cancer. $N$ Engl J Med 1978; 299: 1397-1401.

10. Berggren H, Ekroth R, Malmberg R, Naucler J, WilliamOlsson G. Hospital mortality and long-term survival in relation to preoperative function in elderly patients with bronchogenic carcinoma. Ann Thorac Surg 1984; 38: 633-636.

11. Kohman LJ, Meyer JA, Ikins PM, Oates RP. Random versus predictable risks of mortality after thoracotomy for lung cancer. J Thorac Cardiovasc Surg 1986; 91: $551-554$.
12. Deneffe G, Lacquet LM, Verbeken E, Vermaut G. Surgical treatment of bronchogenic carcinoma: a retrospective study of 720 thoracotomies. Ann Thorac Surg 1988; 45: 380-383.

13. Roxburgh JC, Thompson J, Goldstraw P. Hospital mortality and long-term survival after pulmonary resection in the elderly. Ann Thorac Surg 1991; 51: 800803.

14. Patel RL, Townsend ER, Fountain SW. Elective pneumonectomy. Factors associated with morbidity and operative mortality. Ann Thorac Surg 1992; 54: 84-88.

15. Gebitekin C, Gupta NK, Martin PG, Saunders NR, Walker DR. Long-term results in the elderly following pulmonary resection for non-small cell lung carcinoma. Eur J Cardiothorac Surg 1993; 7: 653-656.

16. Au J, El-Oakley R, Cameron EWJ . Pneumonectomy for bronchogenic carcinoma in the elderly. Eur $J$ Cardiothorac Surg 1994; 8: 247-250.

17. Netherlands Central Bureau of Statistics. Vademecum of health statistics of The Netherlands, 1992. The Hague, SDU Publishers, 1992.

18. Wahi R, McMurtrey MJ, DeCaro LF, et al. Determinants of perioperative morbidity and mortality after pneumonectomy. Ann Thorac Surg 1989; 48: 33-37.

19. Walsh G, Morice RC, Putnam JB, et al. Resection of lung cancer is justified in high-risk patients selected by exercise oxygen consumption. Ann Thorac Surg 1994; 58: 704-711.

20. Thomas P, Giudicelli R, Guillen JC, Fuentes P. Is lung cancer surgery justified in patients with coronary artery disease? Eur J Cardiothorac Surg 1994; 8: 287-292. 